\title{
The bioarchaeology of the Neolithic transition: evidence of dental pathologies at Lepenski Vir (Serbia)
}

\author{
Marija Radović, Sofija Stefanović \\ Laboratory for Bioarchaeology, Department of Archaeology, Faculty of Philosophy, University of Beograd, RS \\ mradovic@f.bg.ac.rs; smstefan@f.bg.ac.rs
}

\begin{abstract}
The Neolithic transition affected human biology, which is visible as a series of interrelated skeletal and dental pathological conditions. The population of Lepenski vir culture, which inhabited the region of the Danube Gorges between 9500-5500 BC, also went through the neolithisation process. In this study, the dental pathological conditions of 32 adult individuals from the Lepenski Vir site were examined for the incidence of enamel hypoplasia, the rate of dental wear, dental caries and ante-mortem tooth loss. The results indicate changes in biology and diet of this population in the Neolithic which were associated with the introduction of non-local identities in the region.

IZVLEČEK - Prehod v neolitik je vplival na človeško biologijo, kar prepoznamo kot serijo med seboj povezanih skeletnih in zobnih patologij. Prebivalci kulture Lepenski Vir, ki so poseljevali območje soteske Džerdap med 9500 - 5500 BC, so bili prav tako priča procesu neolitizacije. Včlanku predstavljava analizo zobnih patologij na 32 odraslih posameznikih iz Lepenskega Vira, na katerih sva iskali sledi hipoplazije sklenine, stopnjo obrabe zob in izgubo zob pred smrtjo. Rezultati kažejo na spremembe v biologiji in prehrani tega prebivalstva $v$ neolitiku, kar se povezuje z uvedbo ne-lokalnih identitet na to območje.
\end{abstract}

KEY WORDS - neolithisation; human biology; dental pathology; Lepenski Vir; the Danube Gorges

\section{Introduction}

The term Neolithic transition refers to the major changes in lifestyle of communities. The stabilisation of these changes includes the transition from huntergatherer lifestyles to agricultural production in the Holocene. The Neolithic transition presents the beginning of human control of the reproduction and evolution of plants and animals (Childe 1936). Rather than adapt to the natural environment, people became the drivers of changes that adapted the environment to their own needs. Considerable effort in researching these processes has been made to understand the consequences of the emergence of agriculture and their impact on human health. Some authors (Cohen, Armelagos 1984; Cohen 1989) argue that a shift from a varied diet secured by hunting and gathering to the monotonous diet based on complex carbohydrates can have a range of adverse effects on human health, reflected in deficiencies in diet and dental caries. According to these authors, a sedentary lifestyle in permanent or semi-permanent settlements and in proximity of domestic animals leads to poor hygiene conditions and the increased prevalence of zoonotic diseases. These theories lead to a paradox in interpreting the significance of the Neolithic transition for the evolution of humans. If cultivation and domestication led to population growth, how can we explain these negative paleopathological patterns? Is there a trade-off between reproductive capacity and health (Stock, Pinhasi 2011. $3)$ ? The answers to these questions lie in studying the Neolithic transition in different regions, because this process did not occur uniformly throughout Europe and was characterised by a number of regional variations.

Several archaeological sites critical for understanding the transition between the Mesolithic and Neolithic in southeastern Europe have been discovered in 
the Danube Gorges between Serbia and Romania during rescue excavations in the 1960s. In particular, several preserved burial sites (Vlasac, Lepenski Vir, Padina and Hajdučka Vodenica), containing around 500 individual skeletal remains and dated to around 9500 to $5500 \mathrm{BC}$, offer a unique opportunity to examine the ways of life and death of these communities. Through an analysis of dental remains, this paper discusses changes in health status and diet throughout the neolithisation period, as well as questions of local versus non-local identities. A single site in particular, Lepenski Vir, was the basis for this research. This study concludes that dental evidence suggests relatively good health of these communities in contrast to other populations in the forager-farmer transition. The results also indicate that changes in the biology of this population led to an improvement in general health, although these changes were not the same for females and males.

\section{Materials}

The Danube Gorges is a magnificent gorge system in the Danube River where it exits from the Hungarian plain. This whole area is characterised by a special microclimate different from surrounding areas (Mišić et al. 1969.210): the location, altitude, configuration of the terrain and bedrock protected this area from harsh climatic fluctuations during the Pleistocene. For these reasons, even the biggest drop in temperature during the last ice age did not influence vegetation. Numerous relict species have survived in the Danube Gorges from the Tertiary to the present day. The special climate and geomorphologic characteristics may well have attracted Mesolithic/Neolithic populations to settle in the area. The Lepenski Vir site is located in the second, Upper Gorge, which is an inaccessible area of the Gorges due to the height of the hills (up to $500 \mathrm{~m}$ ) and the narrow width of the Danube, which is only about $200 \mathrm{~m}$.

Based on 300 radiocarbon measurements from 14 Mesolithic and Neolithic sites in the Gorges, 83 AMS dates have been established from human bones, with 67 dates obtained from the key site of Lepenski Vir (Borić 2008; Borić, Price 2013). These dates reveal a long duration of the Mesolithic (c. 9400$7400 \mathrm{calBC}$ ). The early dates are grouped into two distinct periods, which may indicate two different stages in the framework of the two millennia, but without continuity of settlement. However, the possibility remains that there were many more episodes of occupation not presented with these dates. The phase with trapezoidal buildings probably be- gan $c .6200$ calBC, and most of the buildings had been abandoned by about 5950 calBC, making this phase in the Danube Gorges entirely contemporary with early Neolithic sites in the Morava, middle Danube and Tisza valleys (Whittle et al. 2002) In this paper, this phase will be termed the Mesolithic/Neolithic transformation phase in the Early Neolithic chronological span. This terminology has been proposed by Dušan Borić, who claims that this is the most appropriate term for this key period of the Lepenski Vir culture (Borić 2008.17). Remarkable art in the form of sculpted boulders and innovative architectural features such as the trapezoidal buildings floors found at the site of Lepenski Vir are attributed to this phase. Early Neolithic pottery, polished stone axes, Neolithic types of osseous tool were found associated with trapezoidal buildings at this site. Furthermore, strontium isotope ratios indicate a dramatic increase in the number of non-local, firstgeneration migrants buried in this region, of which five were buried at Lepenski Vir (Borić, Price 2013). On the other hand, lack of domestic animals (with the exception of dogs) and extended supine burials remained as indigenous elements in the material culture of this phase. The period after 5950 calBC is a period of significant change in the lifestyle of these people: a change in mortuary practice (first flexed inhumations appear) and in subsistence (the first domesticated animals appear - goat/sheep, cattle and pigs (Boric, Dimitrijević 2007.52), but the trend of increasing numbers of non-local individuals being buried in this region continued, with seven non-locals females buried at the site (Boric, Price 2013). During this final Neolithic phase, which ended $c$. 5700 calBC, trapezoidal buildings were abandoned at Lepenski Vir, which had become dominant by the Early/Middle Neolithic pattern of habitation (Boric 2011).

Permanent teeth from Lepenski Vir were included in the present study; the material was drawn from the Danube Gorges Anthropological Collection of Laboratory for Bioarchaeology, Belgrade University. Lepenski Vir yielded 134 graves with 190 individuals, in addition to 42 individuals from various unspecified contexts (Roksandić 1996.78). Only teeth (500) that could be related to specific individuals were included in this study (Tab. 1). The remains of 32 adults were available ( 17 males, 13 females and 2 of unidentified sex). Eight of these individuals were dated to the Mesolithic (19, $6 \sigma^{\circ}$ and one of unidentified sex), 15 to the transformation phase (6\% and 90') and 9 to the Neolithic (79, $10^{\prime \prime}$ and one of unidentified sex). Two individuals in this sample dated to 
the transformation phase, and five dated to the Neolithic were of non-local origin (Boric, Price 2013; Table 2.).

\section{Methods}

Four dental parameters were recorded: the prevalence of enamel hypoplasia (LEH) for physiological stress and growth disturbance in childhood; the rate of dental wear for dental use; dental caries and antemortem tooth loss as indices of oral; and general health in relation to diet. Note that a dental calculus was not recorded due to the previous inspection of the sample which showed that a certain amount of this dental plaque had been cleaned after the excavations, which would distort the results. It was not possible to make sex-related observations due to imbalance in the numbers of males and females dating to different periods in the sample: only one female individual is dated to the Mesolithic and one male to the Neolithic.

Enamel hypoplasia is a surface defect of the tooth crown caused by a disturbance in enamel matrix secretion. The prevalence of enamel hypolasia is frequently used to assess the nutritional status and/or the health status of past and present human populations (Goodman et al. 1980; Cohen, Armelagos 1984; Larsen 1997; Hilson 2005; Papathanasiou 2005). Different types of hypopplasia have been identified: pit, plane, furrow, and linear (Hillson 2005). Linear enamel hypoplasia (LEH) was analysed in this study. The prevalence of LEH is analysed as an indicator of physiological stress and growth disturbance in the childhood of individuals examined in this study. By measuring the position of LEH defects on the forming tooth crowns, the common age at which these defects began was also estimated. LEH defects were observed on upper and lower incisors and canines by using the macroscopic method of subdividing the tooth crown surface into zones (Reid, Dean 2000; Hilson 2005.169-176; Fig. 1). The total number of teeth inspected to estimate LEH defects is 239 (Tab. 1) The prevalence of LEH defects is estimated in diversity over chronology and sex.

Tooth wear is caused by teeth grinding and contact with food, cheeks and tongue. This process begins as soon as the tooth emerges from the gingivae and may occur during chewing, but it also occurs at other times, even during sleep (Hilson 2005). The effects of wear are most apparent on the occlusal surfaces, where the teeth of the upper and lower jaws meet. The rate of wear may depend on many

\begin{tabular}{|lcc|}
\hline & maxilla & mandible \\
\hline incisors & 39 & 46 \\
\hline canines & 127 & 27 \\
\hline premolars & 64 & 70 \\
\hline molars & 94 & 133 \\
\hline TOTAL & $\mathbf{2 2 4}$ & $\mathbf{2 7 6}$ \\
\hline
\end{tabular}

Tab. 1. Types of teeth of individuals from Lepenski Vir analysed in the study.

factors: the overall morphology of the crown, developmental defects, the structure of the tooth's hard tissue, the chewing mechanism, diet, and non-feeding behaviours (using the teeth as tools, bruxism etc.). In this study, the nature of dental use of the inhabitants of Lepenski Vir was analysed by recording the rate and patterns of tooth wear. Wear rates (degrees) were recorded on a scale of 0-4, using the scoring systems suggested by Smith and Brothwell (Smith 1983; Brothwell 1981), where 0 refers to no evidence of wear and the $4^{\text {th }}$ degree denotes the total destruction of the crown by wear. The rates of tooth wear were recorded on lower molars (as the first lower molar is the first permanent tooth to erupt and therefore is exposed for a longer time to

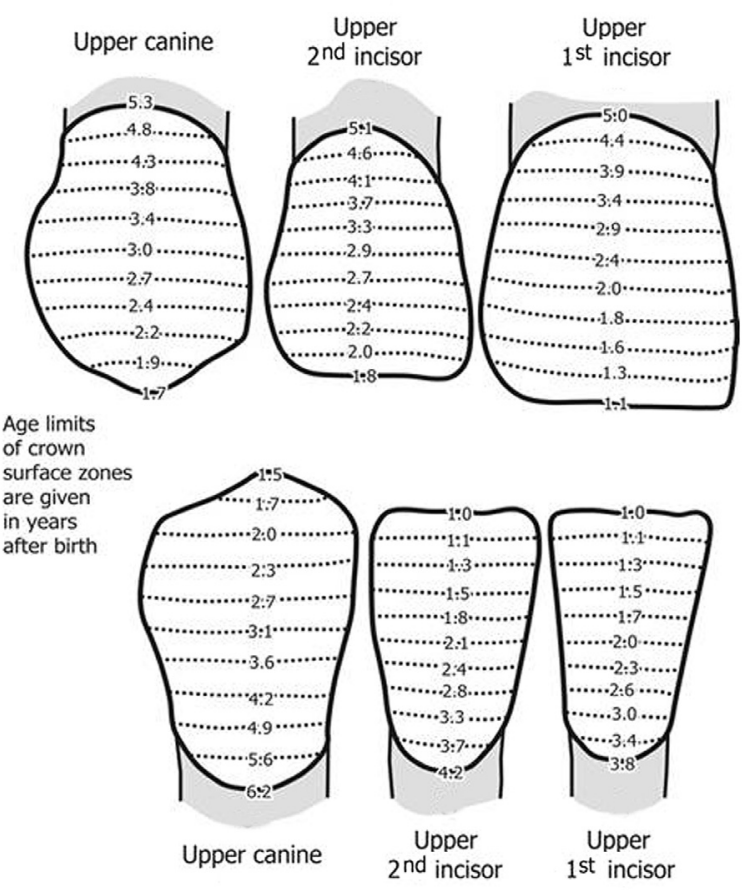

Fig. 1. Formation times for the crown surface in human permanent upper and lower incisors and canines (Reid, Dean 2000). It is apparent that the incisal part of the crowns grows more slowly than the cervical part. The timing of enamel defects is estimated by matching them across the different teeth. Altogether, these tooth crown surfaces provide a sequence from one year after birth, to about six years (redrawn from Hilson 2005.173). 
abrasion caused by diet, whereas the third molar is the last tooth to erupt). The number of teeth available in this sample was 133 (Tab. 1). The results are given in chronological and sex diversity in tooth wear patterns.

Dental caries is a slowly progressive dental disease causing decay of the enamel, dentine and cement. The demineralisation of dental caries is caused by organic acids which form during the fermentation of carbohydrates by plaque bacteria. The strongest association is with the proportion of sugars in the diet. The relationship of other carbohydrates, such as starch, with caries is less clear, but they do seem to have a role (Hilson 2005). Proteins and fats in the diet do not seem to be involved, although there is some evidence that casein, a protein present in milk products, has a protective effect (Bowen, Pearson 1993; Mundorff-Shrestha et al. 1994). In this study, caries lesions were recorded as defined by Hilson (Hilson 2005); a magnifying glass was used for observation. The scoring system records different types of caries lesions: coronal caries, root surface caries and gross caries. These lesions were observed in the whole dentition of individuals from Lepenski Vir (500 teeth in total).

Ante-mortem tooth loss (AMTL) was recorded with the tooth socket both partially and fully healed (Hilson 1996). Ante-mortem tooth loss could be caused by numerous factors, such as dental and periodontal diseases, trauma, high rate of attrition etc. It has been distinguished from post-mortem tooth loss (the tooth has fallen out of the socket) and congenitally absent teeth (i.e. the tooth did not form at all). The calculation of AMTL frequencies was based on the number of absent teeth (per dentition).

\section{Results}

\section{Linear enamel hypoplasia}

The prevalence of linear enamel hypoplasia (LEH) in the teeth of the inhabitants of Lepenski Vir varies from moderate during the Mesolithic and transformation period to relatively low during the Neolithic (Fig. 2). Differences between males and females in the prevalence of LEH were not observable (as the sample included only one female dated to the Mesolithic, and one male dated to the Neolithic). During the Mesolithic, $36.8 \%$ of teeth were affected by LEH defects (14/38); in the transformation phase 33.3\% of teeth were affected by LEH defects (16/48). An evident decline in the prevalence of LEH with $15.5 \%$ of affected teeth $(9 / 58)$ is recorded in individuals

\begin{tabular}{|c|c|c|c|c|}
\hline Grave & Sex & Age & Dating & Origins \\
\hline Iv $7 / 1$ & $\sigma^{\prime \prime}$ & $50-60$ & $T$ & \\
\hline Iv $7 / I I$ & $\sigma^{\prime \prime}$ & $\sim 60$ & $T$ & non-local \\
\hline $\operatorname{lv} 8$ & 9 & $50-60$ & $\mathrm{~N}$ & non-local \\
\hline IV 14 & P & $30-40$ & $\mathrm{~T}$ & \\
\hline $\mathrm{L} 17$ & 9 & $\sim 15$ & $\mathrm{~N}$ & non-local \\
\hline $\operatorname{lv} 16$ & $\sigma^{\circ}$ & oko 30 & $T$ & \\
\hline IV 20 & 9 & $40-60$ & $\mathrm{~N}$ & \\
\hline IV 21 & क & $>25$ & $M$ & \\
\hline IV 22 & $\sigma^{\prime \prime}$ & $40-60$ & $M$ & \\
\hline Iv 26 & $\sigma^{\circ}$ & $20-25$ & $\mathrm{~T}$ & \\
\hline Iv $27 d$ & $\sigma^{\prime \prime}$ & $?$ & $T$ & \\
\hline Iv 28 & 9 & $\sim 40$ & $T$ & \\
\hline Iv $32 a$ & 9 & $50-60$ & $\mathrm{~N}$ & non-local \\
\hline $\operatorname{lv} 37$ & $?$ & $?$ & $\mathrm{~N}$ & \\
\hline Iv 47 & $\sigma^{\prime}$ & $\sim 25$ & $T$ & \\
\hline $\operatorname{lv} 48$ & 9 & $\sim 15$ & $\mathrm{~N}$ & \\
\hline Iv 50 & $\sigma^{\prime \prime}$ & $35-50$ & $M$ & \\
\hline Iv 54d & 9 & $40-50$ & $T$ & \\
\hline Iv 54e & + & $\sim 20$ & $T$ & non-local \\
\hline Iv 60 & $\sigma^{\prime \prime}$ & $20-30$ & $M$ & \\
\hline $\operatorname{lv} 64$ & $\sigma^{\prime}$ & $\sim 50$ & $M$ & \\
\hline lv 64(1) & $?$ & $?$ & $M$ & \\
\hline $\operatorname{lv} 66$ & 9 & $\sim 25$ & $\mathrm{~N}$ & non-local \\
\hline $\operatorname{lv} 69$ & $\sigma^{\circ}$ & $\sim 60$ & $M$ & \\
\hline Iv 73 & $\sigma^{\prime \prime}$ & $45-60$ & $\mathrm{~N}$ & \\
\hline Iv $79 b$ & $\sigma^{\circ}$ & $\sim 30$ & $T$ & \\
\hline $\operatorname{lv} 82$ & $\sigma^{\prime \prime}$ & -30 & $T$ & \\
\hline $\operatorname{lv} 88$ & 9 & $\sim 35$ & $\mathrm{~N}$ & non-local \\
\hline Iv 91 & $\sigma^{\prime \prime}$ & $30-40$ & $T$ & \\
\hline Iv 93 & 9 & $\sim 30$ & $T$ & \\
\hline Iv 105 & $\sigma^{\circ}$ & $35-40$ & $M$ & \\
\hline Iv 122 & 9 & $15-18$ & $\mathrm{~T}$ & non-local \\
\hline
\end{tabular}

Tab. 2. Structure of the sample: $l v$ - Lepenski Vir; M - Mesolithic; $T$ - transformational phase; $N$ Neolithic.

dating to the Neolithic The common individual age at which most LEH defects began was between 2 and 5 years (Fig. 3). Only three LEH defects were recorded as beginning at the age of 6 years (all of them belonged to individuals in the transformation phase). The number of LEH defects (multiple lines per tooth) was highest in individuals dated to the transformation phase. No individuals with single crisis episodes were recorded.

\section{Tooth wear}

The analysis of tooth wear showed a high degree of tooth wear in each period. The average wear for all the teeth inspected (lower left and right molars) is slightly higher in the transformation phase than in the Mesolithic and Neolithic (Tab. 3). This trend is 
more marked on first and second molars (both side), with the exception of right third molars, which are the least worn teeth in the transformation phase compared to the other two periods. The highest rate of wear was recorded in the first molars on each side in each period. A certain degree of asymmetry in the rate of tooth wear in the left and right sides of the dentitions was recorded only in individuals dated to the Neolithic.

\section{Dental caries}

The most common pathological condition in archeological samples, dental caries, was infrequent among the inhabitants of Lepenski Vir. Of 500 inspected teeth, only 7 were affected by dental caries (1.4\%), two premolars and five molars. When analysed by jaw, similar results were obtained: in maxillary teeth, the caries rate was 1.3\% (3/224), and 1.4\% (4/276) in mandible teeth. We recorded two caries lesions on occlusal surfaces and five on root surfaces; no evidence of gross caries was found.

When analysed as groups of individuals dated to three different periods and by individual teeth, significant differences appear. No caries were detected among the individuals dated to the Mesolithic. One female individual dated to the transformation phase showed evidence of caries (Lepenski Vir, grave 47) and two females dated to the Neolithic (Lepenski Vir, graves $32 \mathrm{a}$ and 88 ). The two females dated to the Neolithic were individuals of non-local origin (Boric, Price 2013).

\section{Ante-mortem tooth loss}

Ante-mortem tooth loss (AMTL) among the inhabitants of Lepenski Vir is infrequent: 1.5\% (8/524) of all missing teeth is lost before death (antemortem). Similar results were obtained for maxilary teeth $1.7 \%(5 / 288)$, and mandibles $1.2 \%(3 / 236)$. AMTL was observed only in individuals dated to the Neolithic, one male and four females (Lepenski Vir, graves

\begin{tabular}{|cccc|}
\hline Side & Mesolithic & Transformations & Neolithic \\
\hline Left & & & \\
$M_{1}$ & 2,7 & 2,9 & 2,6 \\
$M_{2}$ & 1,7 & 2,2 & 1,7 \\
$M_{3}$ & 1,5 & 1,5 & 1,7 \\
\hline Right & & & \\
$M_{1}$ & 2,6 & 2,8 & 2,4 \\
$M_{2}$ & 1,8 & 2,3 & 1,7 \\
$M_{3}$ & 1,4 & 1 & 2 \\
\hline
\end{tabular}

Tab. 3. Average rate of tooth wear (scored 0-4) by tooth and period.

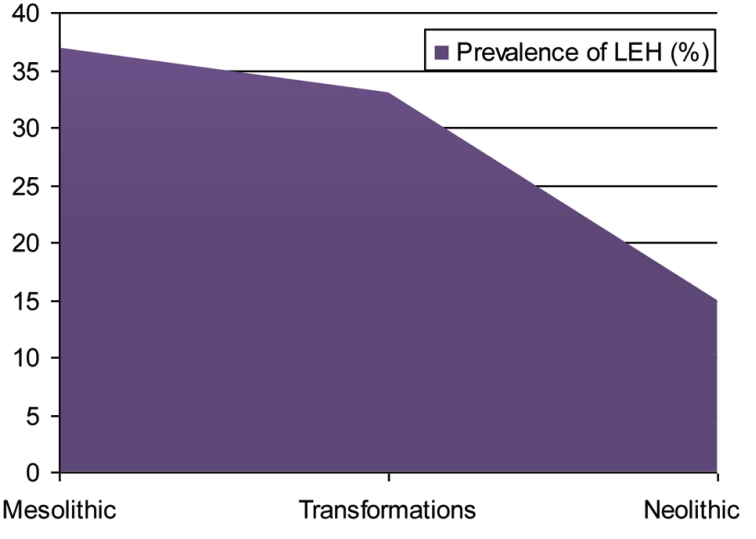

Fig. 2. Prevalence of linear enamel hypoplasia in the teeth of inhabitants of Lepenski Vir (results given in \% of affected teeth).

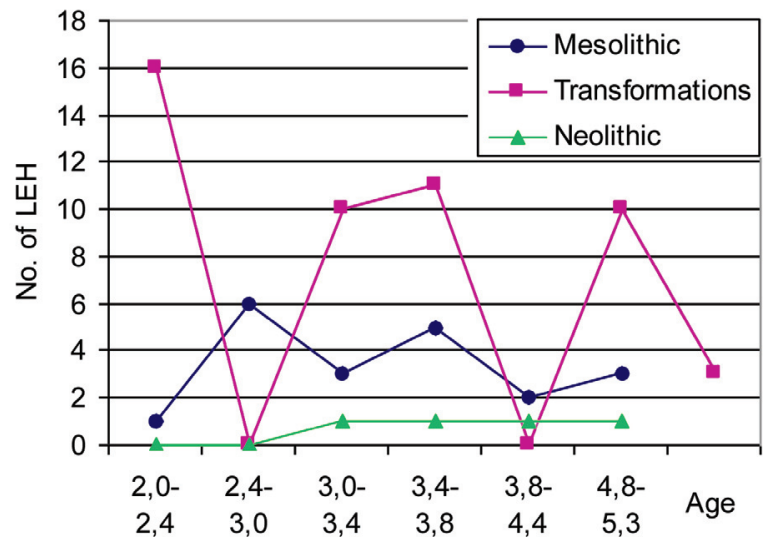

Fig. 3. Number of LEH defects in relation to individuals' age when defects appeared in the Mesolithic, transformation phase and Neolithic at Lepenski Vir.

7/I, 20, 83A, 32a and 88). Three of the females with AMTL were of non-local origin (Borić, Price 2013).

\section{Disscusion}

Recording the incidence and severity of enamel hypoplasia is a standard procedure in physical anthropology (Buikstra, Ubelaker 1994; Hilson 1996; Larsen 1997), and enamel hypoplasia has been widely used to assess stress levels in past and present humans. LEH frequencies can be used to obtain information on health, nutritional status, and periods of transition in subsistence and changes in environmental conditions among both individuals and populations. Because LEH is a non-specific stress marker, the precise nature of a stressful event leading to its formation cannot be deduced from this kind of analysis. But what can be traced are models of stress events through time in an observed population, the number of stress episodes and an individual's age when these stress events occurred. The results of the 
present study demonstrate a reduction in systematic childhood stress from the Mesolithic to the Neolithic in this population. Hypoplasia is recorded as most frequent in the Mesolithic. During the transformation phase, the level of childhood stress decreased very slightly, but the severity of individuals' stress increased according to the number of lines observed per single tooth (Fig. 4). An evident reduction in childhood stress events was recorded for the Neolithic. These results imply that during the Mesolithic and transformation phase, the period of childhood, which is anyway a sensitive period, was worse due to living conditions (i.e. no solid houses, hunting and gathering as relatively insecure means of food supply etc.). The most age at which most of these stress events occurred was between 2 and 5 years, which could be related to weaning stress.

The association between subsistence and diet in correlation with the rate of tooth wear has been studied around the world in various populations (Anderson 1965; Molnar 1971; Scott 1979; Smith 1984; Eshed et al. 2006). All these studies concluded that tooth wear and wear patterns could be used to reconstruct a population's behaviour and diet. The degree of tooth wear in the teeth of Lepenski Vir inhabitants was high in all periods, which suggests no significant changes occurred in the of type of food consumed or the method of food preparation. Since sand tends to grind down teeth surfaces, as described in studies of prehistoric fishing communities on the coast of California (Jurmain 1990), it is not surprising we found marked teeth wear at this site located on a sandy shore. It is also believed that the ingestion of fish, particularly dried fish, encourages a higher rate of tooth wear, as seen in Eskimo groups (Elvery et al. 1998). The Lepenski Vir site is known for its high quantities of fish bones, probably processed by the inhabitants for consumption. The two factors that led to a high rate of tooth wear in this coastal population were sand and dried fish were the same in each period (the Mesolithic, transformation, the Neolithic). The asymmetry of tooth wear rates in the left and right side of the dentitions recorded only in individuals dated to the Neolithic suggests the possible use of teeth in paramasticatory behaviours (Fig. 5). This hypothesis is confirmed by an analysis of non-masticatory traits in this population (Radović in preparation), which shows that the inhabitants of Lepenski Vir used their teeth as tools, especially after the Mesolithic.

Although there were no significant differences in tooth wear rates among the inhabitants of Lepenski

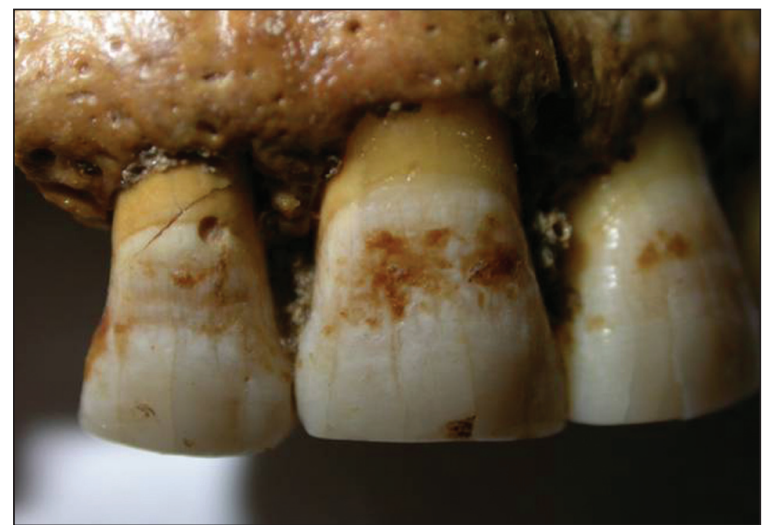

Fig. 4. Burial 50, Lepenski Vir (Early Mesolithic) multiple LEH defects on upper incisors.

Vir, there was a difference in the appearance of dental caries. Dental caries was detected in the teeth of only three individuals (one female dated to the transformation phase and two non-local women dated to the Neolithic) (Fig. 6). But the incidence of caries nevertheless remains very low. Low rates of caries correlate with a low carbohydrate diet, while high levels of proteins and fat are thought to inhibit caries. A diet not rich in carbohydrates and abrasive food (causing high rates of tooth wear) probably inhibited the development of caries in these people. Average frequencies of teeth affected by caries based on a global population study were reported by Turner (1979): $1.7 \%$ for forager populations, $4.8 \%$ for mixed foraging/farming, and $8.6 \%$ for fully agricultural populations. According to these facts, even during the Neolithic the population of Lepenski Vir still depended on foraging - the incidence of caries is no higher than $1.4 \%$, suggesting low levels of carbohydrates in the diet. As a global phenomenon, the dramatic increase in caries rates $(>15 \%)$ was due to the level of sugar products and products high in carbohydrates, including sticky textures, that were included in the diet (Hilson 1979; Sreebny 1983; Kashekt et al. 1994; Larsen 1995). In the Neolithic of Lepenski Vir, this phenomenon was not observed and remains below Turner's average frequencies of teeth affected by caries (4.8\%) for mixed economies (agriculture + foraging) (Turner 1979). Furthermore, caries lesions in Neolithic individuals are detected only among females of non-local origin, which implies that the intake of more carbohydrates could have been related to earlier periods in their lives (and therefore a different subsistence in their places of origin). The analysis of $\delta 15 \mathrm{~N}$ for these two non-local women showed values below 12.0\%o (Bonsall et al. 1997), which indicates a diet based predominantly on terrestrial, or at least combined terrestrial + aquatic, sources. These values of $\delta^{15} \mathrm{~N}$ are 


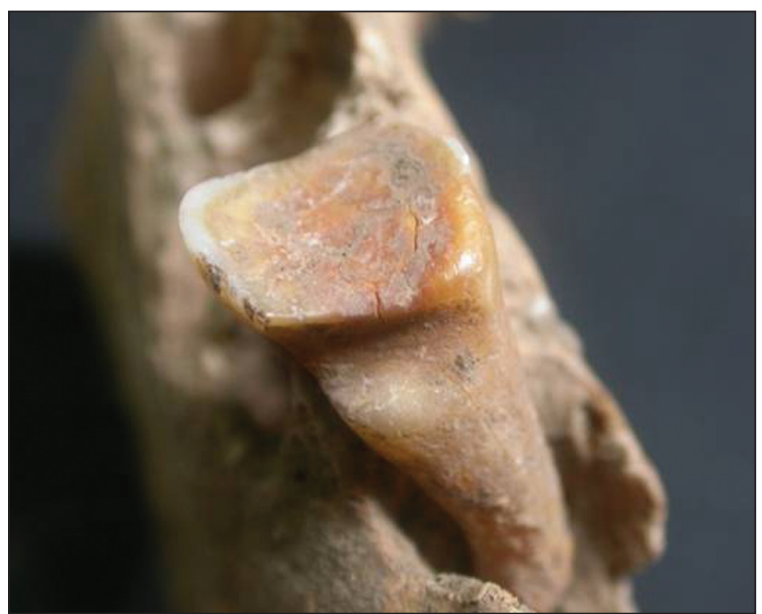

Fig. 5. Burial 31, Lepenski Vir (Early Neolithic) approximal groove on tooth 37.

significantly lower than the values of $\delta^{15} \mathrm{~N}$ in individuals from the Mesolithic at Lepenski vir, whose diet was based on aquatic proteins. Evidence of caries in the teeth of these two Neolithic women combined with different dietary patterns indicated by the $\delta^{15} \mathrm{~N}$ values probably correlates with their non-local origin.

The lack of evidence of ante-mortem tooth loss in individuals dated to the Mesolithic and transformation is in accordance with the absence or low rate of dental caries as one of the major factors associated with tooth loss (Hillson 1986; Armelagos, Rose 1972; Cook 1984; Luckas 1992). Among the Neolithic people, AMTL was detected in seven individuals, only two of whom had teeth affected by caries (graves $32 \mathrm{~A}$ and 88 ). The relatively frequent incidence of AMTL in these people can be attributed to the use of teeth as tools (Radovic in preparation).

\section{Conclusions}

To summarise, the incidence of linear enamel hypoplasia demonstrates a reduction in systematic childhood stress from the Mesolithic to the Neolithic in this population. These results imply possible changes in living conditions that were more suitable for the inhabitants of Lepenski Vir, especially during the Neolithic. The common age at which most stress events began was between 2 and 5 years, which may have been related to weaning stress. On the other

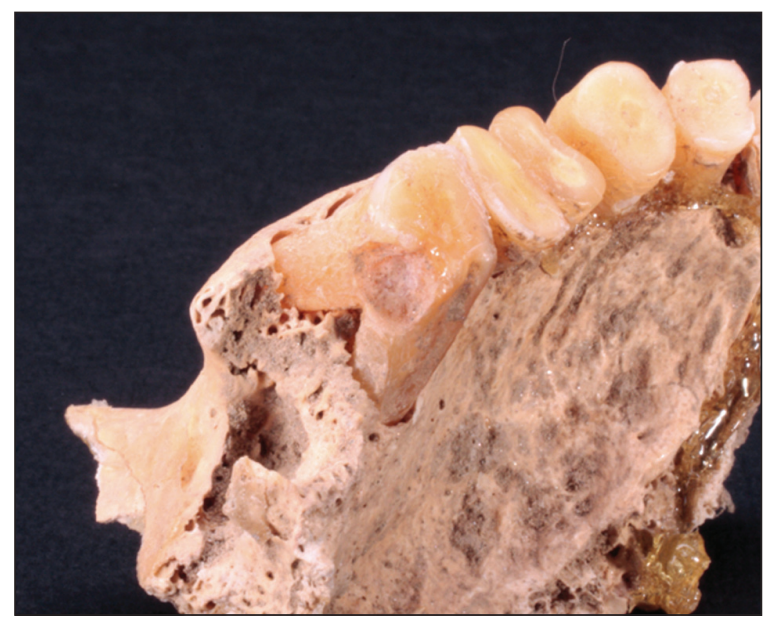

Fig. 6. Burial 32a, Lepenski Vir (Early Neolithic) caries of root surface in first upper molar.

hand, the high rate of tooth wear and low rate of caries (with an absence of caries in the Mesolithic) characteristic for this population, suggests a diet poor in carbohydrates and rich in protein and fat. The incidence of caries can be related to the appearance of non-local individuals in this region. These results also imply that there were no major changes in the food production of this community. A combined terrestrial/fresh water diet and the use of teeth as tools are probably the main reasons for high wear rates in this population.

The results of the present study show that there were no dramatic changes in the biology of the inhabitants of Lepenski Vir over a long period (9500- $c$. 5950 calBC). Protein remained the staple of the diet, but a reduction in childhood stress, the appearance of dental pathologies and increased activities involving teeth as tools after the Mesolithic suggest a certain level of adaptation to the new life style which was brought to the region by the Balkans' earliest farming and stock-breeding communities.

\section{ACKNOWLEDGEMENTS}

This research is a part of the project 'Bioarchaeology of Ancient Europe - humans, animals and plants in the prehistory of Serbia' (III47001) funded by the Ministry of Education, Science and Technological Development of the Republic of Serbia. 


\section{References}

Anderson J. E. 1965. Human Skeleton of Tehuacan. Science 148: 496-497.

Armelagos G. J., Rose J. C. 1972. Factors Effecting Tooth Loss in Prehistoric Nubian Populations. American Journal of Physical Anthropology 37(3): 428.

Bonsall C., Lennon R., McSweeny K., Stewart C., Harkness D., Boronean V., Bartosiewicz L., Payton R. and Chapman J. 1997. Mesolithic and early Neolithic in the Iron Gates: a palaeodietary perspective. Journal of European $\mathrm{Ar}$ chaeology 5(1): 50-92.

Borić D. 2008. Kultura Lepenskog vira u svetlu novih istraživanja. Glasnik Srpskog arheološkog društva 24: 844.

2011. Adaptations and transformations of the Danube Gorges foragers (c. 13,000 - 5500 cal. BC): An overview. In R. Krauß (ed.), Beginnings - New Research in the Appearance of the Neolithic between Northwest Anatolia and the Carpathian Basin. Verlag Marie Leidorf GmbH. Rahden/Westfalen: 157-203.

Borić D., Dimitrijević V. 2007. Apsolutna hronologija i stratigrafija Lepenskog vira. Starinar 57: 9-55.

Borić D., Price D. 2013. Strontium isotopes document greater human mobility at the start of the Balkan Neolithic. Proceedings of the National Academy of Sciences of the United States of America 26(110). 10.1073/pnas. 1211474110.

Bowen W. H., Pearson S. K. 1993. Effect of milk on cariogenesis. Caries Research 27: 461-6.

Brothwell D. R. 1981. Digging up Bones. Third edition. British Museum and Oxford University Press. London and Oxford.

Buikstra J. E., Ubelaker D. H. 1994. Standards for Data Collection from Human Skeletal Remains. Arkansas Archeological Survey. Fayetteville.

Childe V. G. 1936. Man Makes Himself. Watts and Co. London.

Cohen M. N. 1989. Health and the Rise of Civilization. Yale University Press. London.

Cohen M. N., Armelagos G. J. (eds.) 1984. Paleopathology at the Origins of Agriculture. Academic Press. Orlando.

Elvery M. W., Savage N. W. and Wood W. B. 1998. Radiographic Study of the Broadbeach Aboriginal Dentition. American Journal of Physical Anthropology 117: 211-219.
Eshed V., Gopher A. and Hershkovitz I. 2006. Tooth Wear and Dental Pathology at the Advent of Agriculture: New Evidence From the Levant. American Journal of Physical Anthropology 130: 145-159.

Cook D. C. 1984. Subsistence and health in the Lower Illinois Valley: osteological evidence. In M. N. Cohen, G. J. Armelagos (eds.), Palaeopathology at the Origins of Agriculture. Academic Press. New York. 235-69.

Goodman A. H., Armelagos G. J. and Rose J. C. 1980. Enamel hypoplasias as indicators of stress in three prehistoric populations from Illinois. Human Biology 52: 515-28.

Hillson S. W. 1979. Diet and dental disease. World Archaeology 11: 147-62.

1986. Teeth. Cambridge Manuals in Archaeology. Cambridge University Press. Cambridge.

1996. Dental Anthropology. Cambridge University Press. Cambridge.

2005. Teeth. Second edition. Cambridge University Press. Cambridge.

Jurmain R. 1990. Paleoepidemiology of a central California prehistoric population from CA-Ala-329: dental disease. American Journal of Physical Anthropology 81: 323-342.

Kashket S., Yaskell T. and Murphy J. E. 1994. Delayed effect of wheat starch in foods on the intraoral demineralization of enamel. Caries Research 28: 291-296.

Larsen C. S. 1995. Biological changes in human populations with agriculture. Annual Review of Anthropology 24: $185-213$.

1997. Bioarchaeology. Cambridge Studies in Biological Anthropology. Cambridge University Press. Cambridge.

Lukacs J. R. 1992. Dental paleopathology and agricultural intensification in South Asia: new evidence from Bronze Age Harappa. American Journal of Physical Anthropo$\log y$ 87: 133-150.

Mišić B., Čolić D. and Dinić D. 1969. Ekološka-fitocenološka istraživanja, Lepenski vir. Beograd.

Molnar S. 1971. Human tooth wear, tooth function and cultural variability. American Journal of Physical Anthropology 34: 175-90.

Mundorff-Shrestha S. A., Featherstone J. D. B., Eisenberg A. D., Cowles E., Curzon M. E. J., Espeland M. A. and Shields 
C. P. 1994. Cariogenic potential of foods. II. Relationship of food composition, plaque microbial counts, and salivary perameters to caries in the rat model. Caries Research 28: $106-15$.

Papathanasiou A. 2005. Health Status of the Neolithic Population of Alepotrypa Cave, Greece. American Journal of Physical Anthropology 126: 377-390.

Reid D. J., Dean M. C. 2000. The timing of linear hypoplasias on human anterior teeth. American Journal of Physical Anthropology 113: 135-140.

Radović M. in prep. Traces of non-masticatory activities on teeth of inhabitants of the Danube Gorges (95005500 B.C.). Unpublished PhD thesis. University of Beograd. Beograd.

Roksandić M. 1999. Transition from Mesolithic to Neolithic in the Iron Gates gorge: Physical anthropology perspective. Unpublished PhD thesis. Simon Fraser University. Burnaby.

Scott E. 1979. Dental wear scoring technique. American Journal of Physical Anthropology 51: 213-217.
Smith B. H. 1984. Patterns of molar wear in hunter-gatherers and agriculturalists. American Journal of Physical Anthropology 63: 39-56.

Sreebny L. M. 1983. Cereal availability in dental caries. Community of Dental and Oral Epidemiology 11: 148155.

Stock J. T., Pinhasi R. 2011. Changing Paradigms in Our Understanding of the Transition to Agriculture: Human Bioarchaeology, Behaviour and Adaptation. In R. Pinhasi and J. T. Stock (eds.) Human Bioarcheology of the Transition to Agriculture. Wiley - Blackwell. Chichester: 1-41.

Turner C. 1979. Dental anthropology indications of agriculture among the Jomon people of central Japan. American Journal of Physical Anthropology 51: 19-636.

Whittle A., Bartosiewicz L., Borić D., Pettitt P. and Richards M. 2002. In the Beginning: New Radicarbon Dates for the Early Neolithic in Northern Serbia and South-East Hungary. Antaeus 25: 63-117. 